\title{
INTERNALIZATION OF MULTICULTURAL VALUES IN LEARNING ISLAMIC EDUCATION AT MTS YASTI BENGKAYANG
}

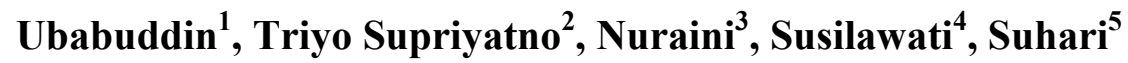 \\ 1,3,4,5 Institut Agama Islam Sultan Muhammad Syafiuddin Sambas, \\ Kalimantan Barat, Indonesia \\ ${ }^{2}$ Universitas Islam Negeri Maulana Malik Ibrahim Malang, Jawa Timur, Indonesia \\ Email: ubabuddin@gmail.com
}

\begin{abstract}
This research was conducted at MTs Yasti Bengkayang. As an educational institution located in the transmigration area and bordered by the State of Malaysia, it has definitely the uniqueness and diversity that has been bought by everyone from their original area, then fused into a multicultural society with the ego and interests of each individual. As an Islamic educational institution in a multicultural society, MTs Yasti Bengkayang always strives to make Islam as a religion of rahmatan lil alamin through the internalization of multicultural values in schools. The purpose of this study was to find out, identify, and uncover multicultural values contained in Islamic religious education learning and instilling methods that have been carried out at MTs Yasti Bengkayang. This method was used qualitative with a case study approach. The results showed that: 1) multicultural values contained in the learning of Islamic religious education at MTs Yasti Bengkayang such as; inclusive values, peace, justice, solidarity, affection, mutual help, and forgiveness; 2) the method of investing in multicultural values were teaching, example, guidance, and habituation.
\end{abstract}

Keywords: Internalization; Multicultural Values; Learning

Abstrak: Penelitian ini dilakukan di MTs Yasti Bengkayang. Sebagai lembaga pendidikan yang terletak di daerah transmigrasi dan berbatasan dengan
Negara Malaysia, ia pasti memiliki keunikan dan keragaman yang telah dibeli oleh semua orang dari daerah asalnya, kemudian menyatu menjadi masyarakat multikultural dengan ego dan minat masing-masing individu. Sebagai lembaga pendidikan Islam dalam masyarakat multikultural, MTs Yasti Bengkayang selalu berusaha menjadikan Islam sebagai agama rahmatan Lil Alamin melalui internalisasi nilai-nilai multikultural di sekolah. Tujuan dari penelitian ini adalah untuk mengetahui, mengidentifikasi, dan mengungkap nilai-nilai multikultural yang terkandung dalam pembelajaran pendidikan agama Islam dan menanamkan metode yang telah dilakukan di MTs Yasti Bengkayang. Metode ini digunakan kualitatif dengan pendekatan studi kasus. Hasil penelitian menunjukkan bahwa: 1) nilai multikultural yang terkandung dalam pembelajaran pendidikan agama Islam di MTs Yasti Bengkayang seperti; nilai-nilai inklusif, perdamaian, keadilan, solidaritas, kasih sayang, gotong royong, dan pengampunan; 2) metode berinvestasi dalam nilai-nilai multikultural adalah pengajaran, contoh, bimbingan, dan pembiasaan.

Kata kunci: Internalisasi; Nilai Multikultural; Pembelajaran.

\section{INTRODUCTION}

As a country, Indonesia is widely known as a pluralistic nation. The diversity of Indonesian society is a reality that must 
be accepted by the whole country as a cultural hasanah that provides its own uniqueness. Sulalah (2012) mentions that differences in Indonesian society are horizontal and vertical. Horizontal differences include social entities based on language, ethnicity, customs, and religion. Whereas the vertical difference is related to the differences in the upper and lower layers which concern the political, social, economic, and cultural fields.

The phenomenon of diversity that exists in Indonesia today is like a doubleedged sword, where the diversity shows the existence of cultural wealth that has the uniqueness and own characteristic. On the other hand, these differences sometimes ignite a fire of hostility that can lead to prolonged conflict between community groups and it will have an impact on social, economic, security, and political instability.

One effort to understand and accept differences are through education that can accommodate all contrast or known as multicultural education. Bank (1993) states that multicultural education as education for people of color.

The presence of an educational institution with a multicultural approach is expected to play a role in reducing the disintegration that occurs amidst the diversity of the Indonesian nation today. An education using a pluralist multiculturalism approach is a process of instilling values of a social way of life to respect each other, be sincere, inclusive, and tolerant of existing cultural diversity. Basically, educational or Islamic educational institutions as social institutions of education and religion, make it possible to bring the process of growth and development of multicultural society. Religious education institutions have the potential to carry out social engineering processes that are oriented towards inclusive education, fair, democratic and multicultural education.

Throughout the observations made by researchers, no specific description of the research has yet been found that studies the internalization of multicultural values in the learning of Islamic education in transmigration and border areas. However, so far there have been several studies that have relevance such as Dakir (2014), his research was more directed to 1) leadership style and 2) the development of the concept of multicultural education values. The research was conducted by Hepni (2015) used a multicasting design that studied and analyzed: 1) values that grow and develop in Islamic boarding schools, 2) strategic steps, and multicultural Islamic education models based on al-Qur'an, hadiths, and inclusive education oriented. Then, Zaenuri and Pratama (2019), the research was conducted in two Islamic boarding schools with typical Nahdhatul Ulama culture, namely Salafiyah-Syafiiyah Islamic Boarding School, Pohuwato Regency and Pesantren Sirojut Tholibin, Gorontalo.

The results showed that these two Islamic boarding schools were proven to have a significant role in instilling pluralist-multicultural values in accordance with NU principles such as Ukhuwaah Wathaniyah, and Ukhuwah Insaniyah, with some steps; First, it forming an egalitarian attitude towards various cultures. Second, habituating collaborative activities together. From the research above no one shows specifically in internalizing multicultural values, exploring existing multicultural values and 
the use of learning methods in shaping students' attitudes and behavior. As it is known, MTs Yasti Bengkayang is an Islamic educational institution that stands in transmigration settlements and also bordered directly by the State of Malaysia. It is what makes this educational institution unique and characteristic of school residents both educational staff, and education, learners and diverse communities. The diversity that exists to date is well established as can be witnessed in social life. This is because educational institutions have an important role in shaping students who have multicultural values as a provision of life in a diverse society.

Observations that have been conducted by researchers at educational institutions indicate that there were efforts to internalize multicultural values, explore multicultural values that exist in school residents, and the application of learning methods in shaping the multicultural character of students.

This study tried to raise how the implementation of Islamic education in transmigration and border areas, especially at MTs Yasti Bengkayang in forming the attitudes and behaviors of students who can respect and appreciate each difference.

\section{RESEARCH METHOD}

\section{Research Method and Approach}

This research tried to examine indepth the learning process that has put forward a pluralist-multiculturalism approach. Aspects that were continuously trying to be explored and studied more deeply, namely multicultural values who developed in learning at schools. The method that was used in this study was qualitative method, by trying to construct

\section{Hasil Penclition}

the reality and understand something that is hidden behind an event that has appeared on the surface.

Through qualitative methods, the writer can find and understand something that is hidden behind phenomena that occur or appear and sometimes difficult to be revealed and understood satisfactorily (Ansen, 2003). The research approach was a case study that is uncovering the complexity of a single case. This is because qualitative research with a case study approach has the slightest view of an event, it has complexity and uniqueness in it (Raharjo, 2010).

\section{Research Site}

This research was conducted at MTs Yasti Bengkayang Regency with multicultural learners. Student culture at MTs Yasti Bengkayang could be seen administratively, everyday life in transmigration and border area. MTs Yasti Bengkayang stands in the transmigration area and bordered with Malaysia. This area was a residential area with diverse backgrounds, ethnicities, cultures, languages, religions, social status, and economic status. Researchers were chosen this location as a place of study with several considerations of characteristics, uniqueness, and in accordance with this research.

\section{Data Collection}

The data sources in this research were human and non-human. The function of human data sources as the main informants, such as the head of Madrasah, teachers, students, and Madrasah committees.

While non-human data sources were soft data or documents relevant to the 
focus of the study such as photographs, drawings, notes, and letters that were related to this research.

In addition, the data was collected using some techniques such as interviews, observation, and documentation.

\section{Data Analysis}

Data analysis used in conducting this study was to analyzed data obtained from interviews, observations and documentation through a process of interpretation by using an interactive model analysis recommended by Miles and Huberman (1984) that data analysis that takes place simultaneously with the data collection process, such as data collection, data reduction, data presentation, and conclusions or verification.

\section{RESEARCH FINDINGS}

\section{Multicultural Values that Develop at MTs Yasti Bengkayang}

\section{a. Inclusive Value}

The implementation of education at MTs Yasti Bengkayang was always strived to accommodate all the interests of students, without this matter delivered by the Head of MTs Yasti Bengkayang. As an educational institution that has diverse students, this institution was continued to instill inclusive values in learning such as inviting students to foster sportsmanship in socializing and living together with other people or other groups, familiarize the deliberations, recognize the existence of universal aspects that might be positive value to other people or other groups with different views, realize that everyone has the potential for the truth or the same rights.

\section{b. Peace Value}

Peace is building togetherness, harmony, brotherhood, and maintaining unity. Peace can be realized depending on the extent to which each individual has an awareness of the importance of mutual respect, appreciation, tolerance, and care for $u k h u w a h$. To realize the peace of this, Islamic educational institution has taught how to overcome or resolve conflicts and hostilities that arise at MTs Yasti Bengkayang, as explained by Tata Nurnanita, head of MTs Yasti that in this institution were always taught cooperation and activities with communities, government institutions, and existing organizations with the aim of togetherness and peace can emerge.

\section{c. Justice Value}

Instilling fair attitude at MTs Yasti Bengkayang was exemplified by teachers through good service without distinguishing cultural background, race, ethnicity, social status, economic status of students, provide equal opportunities for all students, prioritizing the truth, nondiscriminatory, teaching an honesty, sharing, not choosing friends, respecting oneself and others, increasing discipline, learning to be responsible, understanding each individual's dignity, be a person who is sensitive to the feelings of others, immediately apologize if guilty, think about the effects of bad actions before acting rashly, etc. As stated by the Vice Principal Student-Affairs above values of justice were always taught and instilled at MTs Yasti Bengkayang environment.

\section{d. Mutual Help}

In accustoming students' behavior to mutual help, MTs Yasti Bengkayang 
started from the smallest things such as lending school equipment to friends who needed it, cleaning the class in turns, sharing food, participating in cooperation, then donating to friends who got calamity through infaq on every friday and other donation events, helping friends who have difficulty in the learning process or understanding the lesson, giving scholarships from institutions to students who can not afford, students converts, and students achievement.

\section{e. Value of Solidarity}

The formed of solidarity has implications for the compactness and interrelation of the parts that exist. As stated by the head of MTs Yasti, solidarity was very important because human beings are social creatures who live side by side and need others. The role of Islamic educational institutions above in fostering students' solidarity was through joint the events such as extracurricular, religious activities (commemoration of big days), congregational prayers, arts and cultural activities, foster a sense of caring such as visiting and helping the needy or the poor people who need, following national activities and, etc.

\section{f. The Value of Affection}

Affection is a relationship between two or more people as sympathy or friendship. MTs Yasti Bengkayang strongly emphasized affection in the midst of diverse cultural, ethnic, racial, linguistic, cultural backgrounds, social status, economic status, gender. With love, the differences did not make social hostility and conflict. Diversity and the difference must be framed with affection so that harmony and peace emerge.
Affection must be an external mechanism, especially in Muslim relations. As a universal doctrine, Islam teaches compassion to anyone, ukhuwah Islamiah (brotherhood of fellow muslims), ukhuwah Wathoniyah (fraternal compatriots and countrymen), ukhuwah 'ubudiyah (brotherhood in worship), ukhuwah insaniyah and ukhuwah basyariyah (brotherhood in fellow human beings).

\section{g. Forgiveness}

Forgiving others who did the wrong thing was always pursued at MTs Yasti Bengkayang, as conveyed by the Vice Principal Student-Affairs that through the door of forgiveness everyone could open the barrier of separation, broken relationships, hostility, disputes, and clashes. Eliminate bad prejudice, avoid fights, respect differences of opinion, give the door of forgiveness and pray for the good of those who did wrong.

\section{The Method for Instilling Multicultural Values in MTs Yasti Bengkayang}

The learning method used at MTs Yasti Bengkayang was teaching system, uswatun hasanah, guidance, and habituation as described below:

\section{a. Teach}

Implanting multicultural values in MTs Yasti was not only integrated with Islamic religious education but also all subjects. Besides being taught in the class, the internalization of multicultural values was also taught in extracurricular activities. This Islamic educational institution continued to try to teach students about the values of kindness and invites eliminating bad attitudes that exist in students. 


\section{b. Uswatun Hasanah}

As MTs Yasti did before about the concept of multicultural character development through the uswatun hasanah method, such as; First, the principal's example, instructors and other educators who continued to try to set an example directly in social interaction, for example by behaving politely. Second, continually strive to internalize spiritual values, and morals in every subject. For example, instilling multicultural values with exemplary methods during the learning process in the classroom by praying together, giving examples to always smile, greetings, using polite language and so on.

\section{c. Habituation}

The habituation was carried out by MTs Yasti Bengkayang as an educational institution that instills multicultural values had PEKAT program (Brotherhood, Unity, Equality, Peace, Justice, Harmony, Openness and Tolerance). The PEKAT program was carried out routinely and involves, committees, surrounding communities, government, security, and religious harmony forums.

\section{d. Guidance}

Guidance is not carried out in the classroom only but an educator can also apply the process of building a pluralistmulticultural character to students by providing guidance outside the classroom or extracurricular. MTs Yasti Bengkayang had several extracurricular activities that can support the development of multiculturalism and pluralist characters such as drum bands, karate, entrepreneurship, arts, sports, cooperatives, cooperatives, PMR (Red
Cross Youth), recitation practices, worship practices, and other activities. The cultivation of multicultural values was also carried out by utilizing learning media, such as video screenings of exemplary the struggle of the prophet and apostle, the example of Rasulullah, commendable moral behavior, and films that taught the harmony of life. Thus, this would be used as a lesson and motivation for students.

\section{DISCUSSION}

\section{Multicultural Values that Develop at MTs Yasti Bengkayang}

The multicultural values that develop at MTs Yasti Bengkayang, West Kalimantan included good aqidah, increased worship, morality, and the nature of culture. If the aqidah and worship of students were getting better, it would have implications for the behavior and attitudes of students who are good, flexible, and respect diversity. According to Aly (2011), multicultural education has several characteristics, which are principled in democracy, oriented towards humanity, promoting equality and justice, having an attitude of togetherness and peace, and developing attitudes to accept, acknowledge, and respect each difference. In addition, recognition, acceptance, and appreciation of diversity are social attitudes that are indispensable in building good and harmonious relationships in a pluralistic society (Blum, 2001).

The integration of pluralistmulticultural values in the learning process of Islamic education at MTs Yasti Bengkayang, West Kalimantan, such as:

\section{a. Inclusive}

Education was carried out at MTs Yasti Sanggau Ledo, West Kalimantan 
who kept trying as much as possible in accommodating all the interests of students. As an educational institution that has diverse learners, it must always try to instill inclusive values in learning.

Willingness to respect other people or groups is a manifestation of moderate values (Abidin, 2013). It also conveyed moderate characteristics in Islam as noted by Zainuddin (2010), including (1) tawassuth (take the middle way); (2) idtidal (straight and firm); (3) tasamuh (tolerance); (4) tawazun (balance); (5) salam (peace).

The same thing as explained in the research of Zaenuri and Pratama (2019) mentioned that multiculturalist individuals have an attitude al-Ikhlas (sincerity), alAdalah (justice), al-Tawassut (moderation), al-Tawazzun (balance), and al-Tasamuh (tolerance).

The inclusive values above were in line with what was conveyed by Rahim (2016) that every child has the same right to learn, and 2) the existence of children should not be discriminated against, separated, excluded, due to lack of the ability or learning difficulties. These values were constantly being taught at MTs Yasti Bengkayang with the aim students could have an inclusive attitude and behavior.

\section{b. Peace}

Human values are basically a recognition of the plurality, heterogeneity, and diversity of humans themselves. Respecting humanity's values will bring peace and unity because each of the different individuals or groups feels valued and recognized.

The diversity of society could be in the form of religion or beliefs, mindset,

\section{Hasil Penelikian}

ideology, ethnicity, paradigm, needs, social, economic, and others (Ibanatul, 2013).

Humans are social creatures who always need cooperation or help from others in meeting their needs. Thus, everyone must respect the rights of others and should not impose personal interests on other people or other groups such as putting the common interests first, considering the feelings of others, must not insult, help each other, recognize and respect for human rights, develop mutual love based on humanity, provide encouragement in eliciting an attitude of tolerance.

To realize peace, MTs Yasti Bengkayang taught the conflict resolution and the cultivation of multicultural characters such as patriotism, social care, friendship, peace, national spirit, discipline, tolerance, and others. Peace has three meanings namely; peace as an absence of war, peace as a selfless act of love and peace as an absence of violence of crime, presence of justice (Encyclopedia of Wikipedia, 1986).

Islam is a religion that comes with peace missions such as equality, upholding justice, the prohibition of committing a crime, giving freedom, calling for harmony and mutual assistance, encouraging tolerance, and increasing social solidarity (Nurhidayat, 2017).

\section{c. Justice}

Justice is one of the praiseworthy traits that must be possessed by every individual, because by having the value of justice will be able to put things in their place or not one of them. Justice is the basic norm of relationships with others in preventing social alienation (Herawati, 
2014). The value of justice was always taught at MTs Yasti Bengkayang. Instilling the value of fairness in behavior and attitude at MTs Yasti Bengkayang namely by giving examples of how to be fair by the teacher through service without seeing the differences in background inherent in students, giving equal opportunities to all students, promoting the truth and honesty, respecting themselves and other people, increase discipline and responsibility, and try to understand each individual's dignity.

Islamic doctrine on the value of the eighth and equality has been taught by the Prophet Muhammad SAW in managing the diversity of society in Medina, as stated in the Medina Charter.

\section{d. Mutual Help}

Helping each other is an honorable act between fellow human beings. In forming students' attitudes and behaviors to help one another, MTs Yasti Bengkayang was taught from the smallest things such as lending books, pens, erasers and others to friends, participating in mutual cooperation at school and society, carry out infaq on friday and help friends or people affected by the disaster, provided scholarships to converts and poor people which resulting from the economic efforts of the school and, etc.

Helping one another is good behavior which is always suggested in Islam, this has been confirmed in QS. alMaidah verse 2:

$$
\text { وَتَعَاوَنُوْا عَلَى الْبِرِّ وَ الَتَّقْوَى }
$$

Meaning: And cooperate in righteousness and piety.

A study was conducted by Adi Mandala et al. (2018) stated that help has religious value, togetherness, socialization, and economy. These values were always taught and practiced at MTs Yasti Bengkayang environment.

\section{e. Solidarity}

Solidarity is an attitude of unity to always feel a mutual need, own, and help. The efforts made by MTs Yasti Bengkayang, West Kalimantan in instilling the value of solidarity by carrying out activities together among classes, schools, and communities through activities with government organizations or institutions, including FKUB (Forum for Religious Harmony), MABM (Malay Customary Council), DAD (Dayak Customary Council), MABT (Chinese Cultural Customary Council), PITI (Chinese Islamic Association), Javanese Society, Sundanese Association and, etc.

Social service activities implemented at MTs Yasti by involving outside educational institutions that demonstrate good solidarity. Puspa et al. (2018) stated that social service is one of the efforts in developing students' sense of solidarity. This view became the basis of MTs Yasti in developing the value of solidarity through social service activities.

\section{f. Affection}

Affection is a relationship of more than one person as a sense of friendship and sympathy. At MTs Yasti Bengkayang strongly emphasized the values of affection among the diversity of the surrounding community, like maintaining ukhuwah Islamiyah, ukhuwah wathaniyah, ukhuwah 'ubudiyah, and ukhuwah insaniyah.

The value of affection will be seen by suave, attentive, and friendly behavior 
(Hidayati, 2011). In the same line with what happened at MTs Yasti Bengkayang, teachers gave examples of affection, tenderness, courtesy, attention to all students, and provided a sense of friendly, and students were not afraid or embarrassed to convey the problems they face.

\section{g. Forgiveness}

Forgiveness is a commendable attitude that must be possessed, through sincere ways to forgive the mistakes of others without the slightest bit of hatred and revenge. Through the door of forgiveness, everyone will open the distance and obstructions, repair the broken relationships, eliminate hostility and strife.

The noble personality to forgive the mistakes of others contained in the hadith which was conveyed by the Prophet Muhammad SAW that none of you will believe until you love for your brother what you love for yourself. This is what was always taught, practiced, familiarized in these two Islamic institutions that they were entrenched in students.

The content of multicultural values in Islamic religious education learning as explained above should be entrenched and became a multicultural attitude of students in respecting diversity. To maintain the harmony as stated by Sumbulah (2013) that must establish a pattern of harmony through; 1) dialogue and cooperation, 2) repay crime with kindness, 3) increase the regional approach, 4) social cooperation and health services, 5) performing arts, 6) respecting other people's beliefs, 7) prayer.

\section{Hasil Penelitian}

\section{Pluralist-Multicultural Value Instilling in Learning}

The cultivation of multicultural values in the Madrasah Tsanawiyah Yasti Bengkayang was carried out through classroom learning and other activities that support the process of forming a pluralistmulticulturalist character. The methods used in forming pluralist-multiculturalist attitudes and behavior were teaching, exemplary or uswatun hasanah, guidance, and habituation.

The method of instilling of the multicultural character values can be done by several methods as stated by Koesoema (2010) that by teaching, exemplary, setting priorities, the praxis of priorities, and reflection. Whereas the method of instilling of the multicultural character values at MTs Yasti Bengkayang was by teaching, exemplary, guidance, and habituation as conveyed by Tata Nurnanita as the head of Madrasah.

\section{a. Teach}

Teaching is to provide an understanding of the value of kindness, the value of justice, and others, so that students understand what is meant by kindness, justice, and values (Koesoema, 2010). Education in character building according to Zubaedi (2011) that an effort made consciously to realize virtue both for individuals and society as a whole. The same thing was also delivered by Saptono (2011) that character education is a serious effort to form, comprehend, and foster ethical values both for himself and for society as a whole. There were some similarities in establishing of pluralistmulticultural attitudes at MTs Yasti with a study was conducted by Zaenuri and Pratama (2019), the first, by forming 
egalitarian attitudes towards cultural diversity and the second, by the habitual collaboration of joint activities.

An important element in character education was teaching character values so that students have an understanding of the values of good behavior such as religion, tolerance, peace, social care, love for the country, and other character values as stated in the 2013 curriculum which has eighteen-character values.

In shaping pluralist-multicultural attitudes and behaviors, MTs Yasti Bengkayang was not only carried out in the classroom but also outside the classroom, besides that it was also integrated with all existing subjects.

\section{b. Exemplary}

The method of uswatun hasanah or exemplary as a way to show the example, an action, behave that should be imitated by other individuals including students, both those that occur due to the creation of conditions that reflect attitudes that uphold noble values and values, as well as illustrations such as exemplary stories through the media (Ramayulis, 2004).

Exemplary at MTs Yasti Bengkayang was applied by educators as role models such as taking out the trash, erasing the blackboard, discipline, performing congregational prayers and, etc.

\section{c. Guidance}

The guidance method was the assistance given to students who are facing problems. Through guidance, the students will be more focused on carrying out better activities and leading to positive things. Thus, the development of a pluralistmulticultural character can be realized.
An educator has a central role in building students' pluralist-multicultural behavior. Exemplary, guidance and habituation should always be carried out with the hope good behavior can be embedded in students such as being polite, respecting, tolerance, maintaining brotherhood and harmony.

This guidance was always given in the classroom when learning processes and also outside the classroom when extracurricular and all activities both formal or informal in collaboration with government instances and organizations in Bengkayang Regency.

\section{d. Habituation}

The learning method with habituation as an activity carried out repeatedly in order to make students accustomed. Habituation based on the experience, while the habit is something that is practiced (Ibnatul, 2013).

The habituation method applied at MTs Yasti Bengkayang including the program of PEKAT (Brotherhood, Unity, Equality, Peace, Justice, Harmony, Openness, and Tolerance). PEKAT program was implemented routinely and involves local communities and government institutions. With the habituation method, it seeks to provide an opportunity for students to get accustomed to practicing the concepts of their religious teachings and akhlaqul qarimah, both individually or groups in daily life (Muhaimin, 2006).

\section{CONCLUSION}

Internalization of multicultural values in educational learning at MTs Yasti taught the basics of religious knowledge and multicultural values in shaping good character or social 
interaction attitudes as a predictor of Islamic teachings rahmatan lil alamin through; 1) upholding the principles of democracy, equality, and justice; 2) the oriented to humanity, togetherness, and peace; 3) have an attitude of acknowledging and accepting and valuing diversity. The values were developed at MTs Yasti, such as; inclusive values, peace, justice, mutual help, solidarity, affection, and forgiveness.

Besides the method of instilling multicultural values at MTs Yasti were teaching, uswatun hasanah, guidance and habituation. Internalization of multicultural values at MTs Yasti Bengkayang not only carried out in Islamic religious education learning but also integrated with all subjects in intracurricular and extracurricular activities.

\section{REFERENCES}

Aly, Abdullah. (2011). Pendidikan Multikultural di Pesantren. Yogyakarta: Pustaka Belajar.

Al-Hakim, Suparlan., \& Untari, Sri. (2018). Pendidikan Multikultural. Strategi Inovatif Pembelajaran dalam Pluralitas Masyarakat Indonesia. Malang: Madani Media.

Arifin, Syamsul. (2015). Studi Islam Kontemporer. Arus Radikalisasi dan Multikulturalisme di Indonesia. Malang: Intrans Publishing.

Bank, James. A. (1993). Multicultural education:

Historical Development, Dimensions, and Practice, Review of Research in education.

Blum, Lawrence. A. (2001). Anti Rasisme, Multikulturalisme dan Komunitas
Antar Ras. Sinta Carolina, etc. Yogyakarta: Tiara Wacana.

Dakir, (2014). Kepemimpinan Kiai dalam Mengembangkan Nilai Pendidikan Multikultural di Pondok Pesantren Moden Darussalam dan Pondok Pesantren Wali Songo Ponorogo, PPs UIN Maulana Malik Ibrahim Malang.

Hanum, Farida., \& Rahmadonna, Sisca. (2009). Implementasi Model Pembelajaran Multikutural di SD Popinsi DIY. Yogyakarta: Stranas.

Herawati, Yunie. (2014). Konsep Keadilan Sosial dalam Bingkai Sila Kelima Pancasila. Vol 18 No. 1.

Hepni, (2015). Pengembangan Budaya Islam Multikultural di Pondok Pesantren (Studi Multikasus pada Pondok Pesantren Al-Qodiri, AlGhazali, dan Al-Amin Jember), Program Pasca Sarjana UIN Maulana Malik Ibrahim Malang.

Hidayat, Nur. (2017). Nilai-nilai Ajaran Islam Tentang Perdamaian. Jurnal Aplikasia. Vol. 17 No. 1.

Hidayati, Titin Nur. (2011). Pendekatan Kasih Sayang: Solusi Pengembangan Karakter Terpuji dan Akhlak Mulia dalam Diri Anak Didik. Jurnal Falasifa. Vol. 2 No. 2. STAIFAS Kencong Jember.

Ibnatul, Anis. (2013). Pendidikan Nasionalisme Melalui Pembiasaan. Jurnal. UNES.

Kusuma, Doni. (2010). Pendidikan Karakter. Jakarta: Gramedia.

Kinarsih, Kania Puspa., etc. (2018). Membangun Solidaritas Peserta Didik Melalui Kegiatan Bakti Sosial. Jurnal Sosioreligi. Vo. 16 No. 1, UPI. 
Mahfud, Choirul. (2009). Pendidikan Multikultural. Yogyakarta: Pustaka Pelajar.

Mandala, Adi. (2018). Eksistensi Kebudayaan Tolong-Menolong Sebagai Bentuk Solidaritas Sosial Pada Masyarakat Muna. Jurnal Neo Societa. Vol. 3, No. 2.

Muhaimin, (2006). Nuansa Baru Pendidikan Agama Islam. Jakarta: Grafindo Persada.

Muthoharoh., etc. (2013). Pendidikan Nasionalisme Melalui Pembiasaan. Jurnal. UNES.

Naim, Ngainun., \& Sauqi, Achmad. (2016). Pendidikan Multikultural. Konsep dan Aplikasi. Jogjakarta: Ar-Ruzz Media.

Rahim, Abdul. (2016). Pendidikan Inklusif Sebagai Strategi dalam Mewujudkan Pendidikan untuk Semua. Jurnal Trihayu. Vol. 3 No. 1

Raihani. (2016). Pendidikan Islam dalam Masyarakat Multikultural. Yogyakarta: Pustaka Pelajar

Ramayulis. 2004. Ilmu Pendidikan Islam. Jakarta: Kalam Mulia.

Rustanto, Bambang. (2015). Masyarakat Multikultural di Indonesia. Bandung: Remaja Rosda Karya.

Saha, Lawrence. J. (1997). International Ensyclopedia of the Sociolgy of Education. New York: Pergaman.

Shihab, Alwi. (2005). Nilai Pluralisme dalam Islam.Bandung: Nuansa.

Sulalah. (2012). Pendidikan Multikultural: Didaktika Nilai-nilai Universilatas Kebangsaan. Malang: UIN-Maliki Press.

Sumbulah, Umi., \& Nurjanah. (2013). Pluralisme Agama. Makna dan Lokalitas Pola Kerukunan
Antarumat Beragama. UIN-Maliki Press.

Suryana, Yaya., \& Rusdiana. (2015). Pendidikan Multikultural. Suatu Upaya Penguatan Jati Diri Bangsa. Bandung: Pustaka Setia

Syam, Nur. (2009). Tantangan Multikulturalisme Indonesia. Yogyakarta: Kanisius

Zaenuri, Ahmad., \& Pratama, Irja. P. (2019). Basis PluralisMultikultural di Pesantren. Jurnal Conciencia.http://jurnal.radenfatah. ac.id/index.php/conciencia.

Zainuddin. (2010). Pluralisme Agama. Malang: UIN Maliki Press.

Zainuddin. (2019). Merawat Keberagaman dalam Keragaman. Yogyakarta: Magnum.

Zubedi. (2005). Pendidikan Berbasis Masyarakat: Upaya Menawarkan Solusi terhadap Berbagai Problem Sosial. Yogyakarta: Pustaka Pelajar. 